contributed papers, which may be submitted without invitation and must not exceed 2,000 words; (c) summaries or abstracts, which are the same as (b) except that the limit is 500 words. Papers will not be read, but will be circulated in advance; and to facilitate printing, copies should be sent to the author's national committee immediately. Full details may be had on communication to the Secretary, Conference Committee, Specialist Agricultural Conference, c/o Council for Scientific and Industrial Research, 314 Albert Street, East Melbourne, Australia. The telegraphic address is: Coresearch, Melbourne.

\section{Conference of Industrial Research Directors}

A CONFERENe of Directors of Industrial Research is being held during March 11-14 at Ashorne Hill, Leamington Spa, Warwickshire, under the auspices of the Industrial Research Committee of the Feder. ation of British Industries. The chairman of the Rosearch Committee, Sir Wallace Akers, is presiding. The subjects under discussion include relationship between the research department and management and other departments of the industrial organisation; finance and costing, laboratory administration and scientific staff, research programmes and their formulation; application of results of research to production; publications, publicity, information and intelligence; and relationship with research associations, the Department of Scientific and Industrial Research and other Government departments, and universities.

\section{Lectures in Lausanne on the Tubercle Bacillus}

A COURSE of lectures on current scientific research concerning t/s tubercle bacillus is being organised in Lausanne by Prof. P. Hauduroy, director of the Institut of Hygiene and Bacteriology of Lausanne, during April 21-23, 1949. The lecturers will include Pyb. K. A. Jensen (Copenhagen), Prof. P. Hauduroy (Lausanne), Dr. Chain (Rome), Sir Howard Florey (Oxford) and Dr. J. Tréfouel (Pasteur Institute, Paris). The lectures will be given either in French or in English, and a summary in both languages will be distributed beforehand to members of the audience. Each lecture will be followed by a discussion. The enrolment fee is 15 Swiss francs. Particulars can be obtained from Prof. P. Hauduroy, 19 Avenue César Roux, Lausanne.

\section{Colonial Service : Recent Appointments}

THE following appointments in the Colonial Service have been anyounced : J. M. Hay, assistant chemist, Nigeria; f. H. Tack, forest engineer, Uganda; J. Greagley, veterinary officer, Tanganyika; P. T. Heath veterinary officer, Uganda; G. J. Bell, professional assistant, Royal Observatory, Hong Kong ; R. J. Garner, assistant meteorologist, Gold Coast; N. G. Lechmere-Guppy, assistant conservator of forests, British Guiana; A. P. Johnson, assistant meteorologist, Gambia ; N. Kirby, deputy Government chemist, Jamaica; R. D. Pauwels, agricultural chemist, Kenya; J. K. Cox (agricultural officer, North Borneo), senior agricultural officer, North Borneo ; J. Gordon (agricultural officer, Gold Coast), agricultural officer, North Borneo; R. D. Linton (senior agricultural officer, Tanganyika), deputy director of agriculture, Gold Coast; His Highness Tenghu Yaacob ibni al-marhum Sultan Abdul Hamid (principal agricultural officer, Federation of Malaya), State agricultural officer, Federation of Malaya; J.F.
Hughes (assistant conservator of forests, Tanganyika), forest utilization officer, Tanganyika; M. S. Parry (assistant conservator of forests, Tanganyika), sylvi. culturist, Tanganyika; Dr. J. H. Strahan (malaria research officer, Federation of Malaya), professor of social medicine and hygiene, Singapore; L. F. Robertson (senior veterinary officer, Palestine), veterinary officer, Tanganyika; S. Simpson (senior veterinary officer, Gold Coast), director of veterinary services, Gold Coast ; L. J. Chwatt (malariologist, Nigeria), senior malariologist, Nigeria ; K. V. Nicholls (meteorological officer, Federation of Malaya), meteorologist, East African High Commission ; G. K. Read (animal husbandry officer, Palestine), livestock officer, Tanganyika.

\section{Announcements}

H.R.H The Princess Elizabeth, Duchess of Edinburgh has been elected an honorary member of the Royal Institution.

SIR RoBurt Robinson, president of the Royal Society has been elected an honorary member of the Parliamentary and Scientific Committee.

Mr. Hugp Linstead, M.P., secretary of the Pharmacentical Society of Great Britain, has been elected a foreign corresponding member of the Academy of Medicine of France. The Academy, which is the premier medical society of France, was founded in 1820 by Louis XVIII, and its membership is limited to 270 French and 80 foreign members.

The Bessemer Medal for 1949 of the Iron and Steel Instibute has been awarded to Prof. J. H. Andrew, professor of metallurgy in the University of Sheffield.

THE Unjversity of Liverpool Chemical Society Medal fo this year has been awarded to Prof. F. S. Spring, of the Royal Technical College, Glasgow. The presentation will take place at the annual open meeting of the Society, when Prof. Spring will deliver an address entitled "The Chemistry of Aspergillic Acid".

Dr. F. F. DANIELl has been appointed to the University chair of zoology tenable at King's College, London, as from October 1, 1949.

THE Rockefeller Foundation has made a grant of 15,000 Zollars for the purchase, primarily, of infra-red spectroscopic equipment in the United States, for ase in the University Chemical Laboratory, Cambridge, under the direction of Prof. A. R. Todd. The equipment is to be used in developing and furthering researches in that Laboratory on nucleotide and nucleic acid structure, and on other chemical investigations of biological importance.

THE feond award of $£ 50$ of the Oliver Memorial Fund will be made to a British subject for a notable contribution to the research, organisation or donor aspect of blood transfusion. Applications and suggestions should be sent, before June 30, to Mr. F. W. Mills, National Provincial Bank, Ltd., Holborn Circus, London, E.C.1.

THE British Iron and Steel Research Association is to hola a conference during May 9-10, 1949, at Ashone Hill, near Leamington Spa, to discuss the proctical applications and essential theoretical treatments of phase-contrast microscopy, the multiplebeam interference technique, and the reflecting microscope. Application to attend and for accommodation at Ashorne Hill should be made to the Metallurgy Division, B.I.S.R.A., 11 Park Lane, London, W.1. 